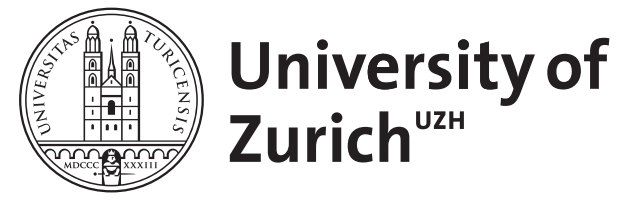
Archive

University of Zurich

University Library

Strickhofstrasse 39

CH-8057 Zurich

www.zora.uzh.ch

Year: 1967

\title{
Vowel Quality in Unstressed Syllables
}

Schubiger, Maria

DOI: https://doi.org/10.1093/elt/xxi.2.170

Posted at the Zurich Open Repository and Archive, University of Zurich

ZORA URL: https://doi.org/10.5167/uzh-154996

Journal Article

Published Version

Originally published at:

Schubiger, Maria (1967). Vowel Quality in Unstressed Syllables. ELT Journal, XXI(2):170-178.

DOI: https://doi.org/10.1093/elt/xxi.2.170 


\section{Vowel Quality in Unstressed Syllables}

MARIA SCHUBIGER Unlveralties of Zurtch and Basel

IT IS CHARACTERISTIC of present-day spoken English that in unstressed syllables vowels and some diphthongs are often reduced to a neutral sound of little sonority, mostly a, often I, occasionally u. Spelling gives no hint as to whether the reduction takes place or not. We say prefect 'prl: fekt but perfect 'po:fikt, Lapland 'læplænd but Finland 'finland, August ' 2 :gast but august $\supset: ' g \wedge s t$, formality $f \circ:$ 'mælitl but forgetfulness fa'getflnis and so on. It seems a perfect maze. On closer observation, however, we discover various motive forces which either favour vowel reduction or tend to check it. It is the purpose of this article to give an account of these forces, so that the student of English may more easily thread his way through the maze.

\section{Unstressed Syllables of Polysyllabic Words}

1. Rhythm plays a prominent part. There is a tendency in English to reduce syllables adjacent to the stressed one, and to place a subsidiary stress on those at one remove from it. The semistressed syllable preserves its vowel quality. ${ }^{1}$ This occurs almost regularly before the main stress, e.g.

magazine ,mægə'zl:n, politician, pəll'tifn, artisan, a:tl'zæen

transformation, trænsfa'meljn, economic, 1 : kə'nomik

Compare: remain rl'mein with recognition, rekəg'nifn

prosaic pro'zelik with provocation ,provo'kelfn defend di'fend with degradation, degra'del $\int \mathrm{n}$

Note. This alternation of stressed and unstressed syllables, of strong and weak vowels, is sometimes overridden by the tendency to preserve in a derivative the stress and vowel of the word it is derived from, in other words by analogy.

We say examination ig,zæmi'nelfn (to examine ig'zæmin) appendicitis $ә$,pendi'saitls (appendix ə'pendlks) pronunciation pro, nansl'eifn (to pronounce pro'nauns)

but canalization, kænəlal'zeifn (to canalize 'kænəlaiz) harmonization, ha:man al'zelfn (to harmonize

'ha:manaiz) characteristic ,kærəktə'rlstik (character 'kærəktə)

\footnotetext{
${ }^{1}$ All we can say for certain is that the two phenomena are interdependent. A subsidiary stress favours the preservation of the full vowel; a full vowel produces the impression of a subsidiary stress.
} 
Likewise, the frequent preservation of a strong vowel in the syllable immediately preceding that carrying the main stress is in many cases supported by analogy, e.g.

virginity va:'dzinitl (virgin 'va:dzin)

fertility fa: 'tillitl (fertile 'fo:tail)

formality fo: 'malit (formal ' $f$ : mal)

mortality mo:'tzlitl (mortal 'mo:t)

normality no:'malitl (normal ' $n:$ mal)

morbidity mo:'biditl (morbid 'mo:bid)

A subsidiary stress can also fall on a syllable at one remove after

the main stress, e.g.

intellect 'inta,lekt, dialect 'daia,lekt, catalogue 'kæta,bg,

dialogue 'daia, bg, episode 'epl, soud, cataract 'kæta, rækt,

gramophone 'græmə, foun, telegram 'tell,græm,

caravan 'kæra, væn, atmosphere 'ætmas, fla, escalator 'eskə, leita, refrigerator ri'frid $3 \partial_{\text {, reita. }}$

But very often two or three completely unstressed syllables, with weak vowels, follow upon the main stress, ${ }^{1}$ e.g.

hurricane 'har/kan, calendar 'kalanda, vegetable 'vedzatəbl, comfortable 'kAmftabal, melancholy 'melajkali, particular po'tikjala, graduate 'grædjult, experiment ik'sperimant. ${ }^{2}$

2. Frequency and therefore familiarity of a word favours reduction; while unfamiliarity often checks it, even in a syllable adjacent to the full stress. Compounds are good instances in point:

We must say England, Holland, Finland, Shetland, Switzerland, Northumberland, highland, lowland (-land).

But we can say Lapland, Thailand, Greenland (-lænd), and we must say Heligoland, Disneyland, wonderland, fairyland (-land).

We say milkman, postman, chairman (of a meeting), footman (-man); but snowman, chairman (in a park) (-mæn); gentleman (-man); but handyman (-mæn).

We must say strawberry, blackberry, bilberry, raspberry (-bari); but we can say dewberry (-beri).

Sunday, Monday, Tuesday, holiday, Saturday can be pronounced $-d e l$ or -dl; Doomsday, Boxing-day only -del.

Weakening of vowel quality is on the increase today, e.g. despot 'despot, 'despat; product 'prodakt, 'pradakt;

\footnotetext{
${ }^{1}$ The end of a mord resists detrition much less than the beginning. This is a phenomenon observable in many languages and at many stages of their evolution.

'Verbs in -ment and -ate carry a secondary stress on the suffix, which retains its full vowel; e.g. to experiment iks'perl,ment, to separate 'sepo, reit. Some nouns can be stressed and pronounced like the corresponding verbs: estimate 'estl, meit or 'estim/t, associate $จ$ 'sou Jl, eit or a'sou Jiit.
} 
suburb 'sıba:b, 'sıbab; record 'reko:d, 'rekad; garage 'gæra: 3 , 'gærid 3.

Many words resist this trend, especially those in ou and (1)u: ; e.g. window 'windou, shadow 'sædou, narrow 'nærou, piano 'pjænou, tomato tə'ma : tou, nephew 'nev ju, argue'a : g Ju :, value 'valju:, tissue 'tisju:.1

3. Meaning, namely the fading of the meaning of the component elements of a compound word, is responsible for many sound reductions, some of long standing.

Compare saucepan 'sJ:span with ashpan ' $x$ [pæn, stewpan 'stju: pren, and with sauceboat 'ss: sbout

cupboard 'kabad with blackboard 'blakbo:d and with cupbowl 'kapboul

forehead 'forid with spearhead 'splohed and with forelock ' $f \jmath$ : bk

shepherd 'Sepad with goatherd 'goutha:d and with sheepskin 'fl:pskin

walnut 'wo: Inat(-nat) with peanut 'pl:nat and with wall fruit 'wo: Ifru:t

chestnut 't $t$ esnat(-nAt) with peanut 'pl:nat and with chest-note 't $t$ estnout.

Note. There is a reaction today against the ever-increasing reduction of sounds and the resulting discrepancy between spelling and pronunciation. It is called spelling pronunciation. Here are a few examples:

waistcoat 'weiskout is newer than 'weskat.

landscape 'lendskeip is practically the only form today;

'lanskip is old-fashioned.

comrade 'kımreid is newer than 'kJmrld, 'kamrid.

venison 'venizn is newer than 'venzn.

Which weak sound $\longrightarrow, 1, u$ or zero-is appropriate in a given word?

The least sonorous vowel is a. All the open or semi-open vowels $(x, a:, \supset, \supset:, \wedge, \partial:)$ are reduced to ə; e.g.

accept ak'sept, herself ha'self, steadfast 'stedfast,

to contest kan'test, Augustine a'gastin, to subject sab'dzekt.

With a few exceptions, also e can be reduced to $ə$, but here there is the alternative 1. Side by side with $ə, 1$ appears chiefly in prefixes and suffixes; e.g.

become bi'kım ba-, defend d'fend da-, prefer prl'fa: pra-, return ri'ta:n ro-, actress 'aktris -əs, friendless 'frendlis -ləs, fondness 'fondnis -nəs, pocket 'pokit -ət, quickest 'kwik/st -əst, linen 'linin -an.

1'winde, 'nevl are sub-standard pronunciations. 
There is the same alternative with the suffixes -ace, -ate, -ain; e.g. palace 'pælis -əs, private 'pralv/t -ət, captain 'kæpt/n -әn. The suffix -age, however, is always pronounced -Id3; e.g. package pækidz, damage 'dxmidz, village 'vilidz.

In all these prefixes and suffixes $ə$ is gaining ground. ${ }^{1}$ With the grammatical endings -es and -ed reduction to $ə$ is not received pronunciation (RP) and should be avoided. It blurs the difference between many pairs of words, such as offices 'rfisiz, officers 'ofisaz, raises 'reiz/z, razors 'relzoz, counted 'kaunt/d, countered 'kauntad. For the same reason $ə$ is avoided with effect l'fekt, except $\mid k$ 'sept, precede prl'sl:d. This distinguishes them from affect a'fekt, accept ak'sept, proceed pra'si :d.

The sound I is normally not reduced to ə; e.g. Latin 'Iatin, habit 'hæbit, animal 'ænimal.'

The diphthong al is either preserved or reduced to I. In the initial syllable di- it is mostly reduced; e.g. to digest di'dzest, direct di'rekt, dilemma di'lema, divan di'væn. It is preferably preserved in minute(adj.) mai'nju :t, idyllic ai'dilik, finance fal'næns, identity al'dentiti, tribunal trai'bju :nal. It is always preserved in ideal ai'dial, gigantic dzal'gæentik, finality fal'nælitl, criterion kral'tləriən, priority pral'oritl, migration mai'grelfn, triangular tral'æogjula, and in most words in -ile: agile 'ædzall, hostile 'hostail, textile 'tekstail, senile 'sinnail. ${ }^{8}$ It is also preserved in many words in -ite: contrite 'kontralt, appetite 'xpətalt, parasite 'pærəsait, dynamite 'dainəmait.

The diphthong ou is either preserved or reduced to ə, occasionally to u; e.g. diplomatic dipla'matlk, irrevocable i'revakabl.

Elision of the unstressed vowel is very frequent in quick speech; e.g. history 'histrl, terrifically ta'rlfikll, 4 university junl'va:stl, Catholic 'kæellik, prisoner 'prizna, properly 'propll, I expect ai'kspekt. Some elisions are still considered very colloquial, e.g. cigarette sig'ret, possible 'posbl.

Sometimes a possible confusion of two meanings prevents the elision. Compare business, sometimes spelt busyness 'bizinas (state of being busy), with business 'blznas (enterprise)

practically 'præktikall (in a practical way) with practically 'praktikll (nearly, so to speak) awfully ' $s$ : full (terribly) with awfully ' 2 :fll (very).

\footnotetext{
${ }^{1}$ Some British speakers react unfavourably to this a even today. Some time ago a reviewer of a radio play based on Pride and Prejudice wrote: 'I wish they didn't call her Miss Bennut'.

${ }^{2}$ Americans tend to say 'latan, 'habat, etc.

Americans say 'zdzil, 'hostil, etc.

'Spelt also terrificly.
} 
Elision does not always reduce the number of syllables. The adjacent consonant-mostly 1 or $\mathbf{n}-$ may become syllabic. This, too, is very frequent; e.g. happen 'hæpก, version 'va: $\int \mathrm{n}$, useful 'ju:sfl, ordinary ' $\supset: d n ̣ r l$, marshal ma:Jl, cardinal 'ka:dṇ|.' The same phenomenon can be observed in short sentences; e.g. Get along 'get'|ग), never mind 'nev'maind.

Between two nasals, however, elision is inadmissible in RP; e.g. woman 'wumən, German 'dza:mən; also between stop+nasal and nasal; e.g. London 'IAndon, Anthony 'zenteni.

On the other hand elision is compulsory with -ten, -den, -ton, -don, -tan, -dan following upon a vowel; e.g. kitten 'kItn, Eden 'I:dṇ, Newton 'nju:tṇ, Gordon 'gJ:dṇ, Satan 'seltn, Wodan 'woudn. It is optional if a consonant precedes, e.g. golden 'gould(ə)n, Boston 'bəst(ə)n. It is also optional with -tern, -dern, -tain; e.g. pattern 'pæt(ə)n, modern 'məd(ə)n, curtain 'kə:t(ə)n, captain 'kæpt(ə)n.

As a result of elision consonant clusters like pl, $\mathrm{kr}$ emerge. They are not, however, at least not in the early stage after the elision took place, quite identical with the same clusters of long standing. Contrary to $\mathrm{Pl}, \mathrm{cr}$ in words like please $\mathrm{p} ! \mathrm{l}: \mathrm{z}, \mathrm{cry} \mathrm{kral},{ }^{2}$ where l and $r$ are devoiced under the influence of the preceding voiceless consonant, these new clusters have a voiced second consonant; e.g. police pll:s, career kria. The a has disappeared, but in disappearing has left its mark upon the following consonant. Here are some phrases and sentences for comparison:

Please call the police 'p!l : z ' $k J: 1$ or 'pll is

Two ships collided on the Clyde 'tu: 'Jlps 'klaidid on ob 'klald A cranky career o 'kræjkl 'kriə.

The last stage, elision without leaving a trace, was reached long ago with words like history 'histrl, pram (perambulator) pram, perhaps præps. It has been reached by some speakers of RP with solicitor 'slisto, police station ' $P ! l$ is steifn, though less frequently with police p!l :s.

Note. By this process new consonant clusters have emerged, or are on the point of emerging, which have for a long time been absent from the phonemic set-up of English:

Initial kn- It disappeared in the 15-17th centuries in words like 'to know, knife'. It is reappearing in words like 'to connect'.

$R+$ consonant lt disappeared in the 16-17th centuries in words like 'learnt'. It is reappearing in words like 'parent, apparent'.

\footnotetext{
In, I stand for syllabic $n, l$.

2., $\mathrm{r}$ stand for devoiced I,jr.
} 
Initial pn- The $\mathrm{p}$ is not sounded in pneumonia, pneumatic. But pn- is pronounced by some speakers in Penelope, peninsula.

Initial $\mathrm{mn}$ The $\mathrm{m}$ is not sounded in mnemonic, but $\mathrm{mn}$ - is pronounced by some speakers in menagerie, minority.

\section{Grammatical Form Words}

Grammatical form-words can be reduced in a way similar to that in the weak syllables of content words:

\begin{tabular}{|c|c|c|c|c|c|}
\hline Strong form & . & have hay & and and & of $\mathrm{Jr}$ & but bAt \\
\hline Reduction of vowel & . & hav & end & əv & bot \\
\hline Elision of the vowel. . & . & & nd & $\mathbf{v}$ & \\
\hline Elision of a consonant & . & $\theta v, v^{1}$ & $n$ & 0 & \\
\hline Strong form & .. & were wo: & be bl: & him him ${ }^{8}$ & \\
\hline Reduction of vowel .. & . & wo & $b^{2}$ & & \\
\hline Elision of the vowel. . & 列 & & & & \\
\hline Elision of a consonant & . & & & im & \\
\hline
\end{tabular}

Whether we use a reduced form, and which reduced form, depends on various factors, some purely phonetical, some functional.

1. Contrary to the content word, where a difference of speed is rarely responsible for two competing pronunciations, rapidity of utterance is of great importance here, e.g.

Slow: you and I 'ju: and 'al

Quick: 'ju: on 'al

Slow: a pint of milk ə 'paint əv 'milk

ə 'paint a 'milk4

Slow: Look at that balloon 'luk at Oxt bə'lu:n

Quick:

Slow: Yes, sir 'jes sa:

Quick: 'jes sab

Note. In very slow, deliberate utterance, such as public speaking, or in the exposition of an intricate theme, form-words often retain

\footnotetext{
${ }^{1} \mathrm{~h}$ vanishes most easily when there is an $\mathrm{h}$ at the beginning of an adjacent content word, which cannot be dropped; e.g. I saw his house ai 'ss: iz 'haus. Hunt has hurt his head 'hant oz 'ha:t iz 'hed.

${ }^{8} \mathrm{Be}$, been, she, we, me, he sometimes reduce i: to $l$ in unstressed position; you, who can reduce $u:$ to $u$.

' $H$ im, his, it, its, if, in, with always preserve the vowel i.

Poster: Drinka Pinta Milka Day.

"Caption: Looka that bloody Balloon.

'Sir is an enclitic, i.e. a short unstressed word appended to a stressed one here and therefore treated like a form-word.
} 
their strong vowel. Even the articles are sometimes said without vowel reduction, especially the definite article; e.g.

'We are impressed by the ( $\mathrm{Ol}:$ :) consistency of this young boy, by the ( $81:$ ) singlemindedness with which ....'

'Ladies and Gentlemen, It is a (ei) very great pleasure ...'

2. The pronunciation of a form-word can also depend upon the following sound; e.g.

Saint Andrew snt 'ændru :, Saint Thomas sn 'toməs' Bill and Alice 'bil ond 'zlis, Bill and Tom 'bll on 'tom² At one o'clock at 'wan ə'klok, at ten o'clock ə 'ten ə'klok She has $\int I(:)$ 'hæz, She is $\int l:{ }^{\prime} / z^{8}$ to go to gou, to eat tu $1: t$ She got rid of us fi got 'rid av as,

She got rid of them $\int 1$ got 'rid a Bam.'

3. Function can play a certain part. Some form-words have several grammatical functions, not all equally weighty, and are treated accordingly.

(a) The demonstrative pronoun that has no weak form. Even when it is unstressed, it is pronounced bat; e.g.

That's your fault bæts 'juə fo:lt, That's difficult orts 'difikalt.

Note. This, these, those are not shortened either, except occasionally this in phrases like this morning, this evening.

The conjunction and the relative pronoun that are pronounced bot; e.g.

I know that you are free al 'nou dat ju a 'fri:

It's the best that I can do for you its do 'best dət al kən 'du : fo ju :.

(b) Have (had, has) is reduced considerably when it functions as an auxiliary; e.g. I've seen him alv 'si in him, He's done it hl:z 'dAn It. It is not reduced when it is a full verb in the meaning of 'to possess', or when it stands for another verb; e.g. We have a Vauxhall wl hav a 'voks'ho:l, We have lunch at one o'clock wl hav 'lants ət 'wan ə'klok.

It is not reduced either when it means 'to cause something to be done'; e.g. Last autumn we had our kitchen whitewashed . . . wl haed aua 'kltjon 'waltwojt.

(c) Some sm is a partitive word corresponding to French du,

\footnotetext{
${ }^{2}$ Saint being here a proclitic, behaves like a form-word.

'Today on, $n$ are almost general, whether there follows a vowel or a consonant. With saint the $\mathrm{t}$ is not dropped before a vowel.

to be at home to bi(:) at houm, to be in bed to bi: In bed.

'Of is most frequently reduced to o before the similar fricative consonsint 8 .
} 
de la, des, German etwas, einige; e.g. Get me some bread and some apples get $\mathrm{ml} \mathrm{sm}$ 'bred $n \mathrm{sm}$ 'xp/z.

Some sAm is an indefinite word, corresponding to French quelque, German irgend ein, etwelche; e.g. There must be some secret dea 'mast bl sAm 'sl:krit. I heard with some surprise that . . . al 'ho: d wio sAm sa'pralz . . .

(d) Us, the object case of the pronoun we is pronounced as; e.g. He met us in the hall hi: 'met os in oa 'ho:l. He let us off lightly hl: 'let as 'of 'laitli.

It is shortened to $s$ in the phrase Let's ..., where its grammatical function has faded; e.g. Let's go to the pictures 'lets 'gou to ठa 'piktjaz.

The following form-words are hardly ever weakened:

on on on Monday on 'mandi, It depends on me it di'pendz on ' $\mathrm{ml}$ :, On my desk on mal 'desk, Cf. And my desk an mai 'desk.

or J: One lump or two 'wan 'IAmp ग: 'tu:? Black or white 'blak s: 'wait?

The pronunciation is a in phrases like two or three 'tu: a ' $\theta r l$ :, for a minute or two far a 'mlnit a , tu:, more or less 'mo:r a 'les.

their is always $\partial \varepsilon ə$ before a consonant; e.g. their mother $\delta \varepsilon ə$ ' $m \wedge \delta \partial$, their books $\delta_{\varepsilon ə}$ 'buks. It is occasionally $\delta \partial$ before a vowel, for here it cannot be mistaken for the definite article; e.g. their uncles $\delta ə r$ ' $\wedge$ gklz.

The indefinite pronoun there is pronounced ob. As it always precedes a verb, it cannot be mistaken for the article.

your is nearly always pronounced jo: ; e.g. Your book jo: 'buk. In familiar speech it is occasionally reduced to ja; e.g. What's your name 'wots jo 'neim?

not is either reduced to non-syllabic $-n^{\prime} t$ and attached to an auxiliary (don't, can't, etc.) or it preserves its full vowel; e.g. You mustn't (must not) disturb me ju 'masnt (mast not) di'sta:b ml:. Only cannot is occasionally reduced to 'kanat.

$m y, b y$ are rarely reduced to $\mathrm{ml}$, bl. We say my lord $\mathrm{mi}$ 'lı:d, my lady $\mathrm{ml}$ 'leidl. Otherwise $\mathrm{mi}$ and bl are only used occasionally in familiar or jocular style; e.g. Come along my child ' $k a m$ ə'lon $\mathrm{ml}$ ' $\mathrm{t}$ alld, Never in my life 'nevar in $\mathrm{ml}$ 'laif, You must do it by yourself ju mas 'du : It bi jua'self.

Note. Final prepositions, though unstressed, retain the strong vowel; e.g. What are you laughing at 'wot a ju 'la :fin at?

Where have you come from 'wea hav ju 'kum from? 
Likewise, a preposition followed by an unstressed personal pronoun very often preserves its strong vowel; e.g. Fortune disposed otherwise of me 'fo:t $\int \mathrm{n}$ dis'pouzd 'Aठ̆əwaiz ov ml: I had great respect for it al hæd 'greit rl'spekt fo:r it.'

FOR THE YOUNG TEACHER-1

\section{The Incidental Presentation of Teaching Items (1)}

A. S. HORNBY

IT IS GENERALLY agreed today that important teaching items should first be presented orally. An oral presentation of the new item by the teacher is followed by oral drills for the class.

It sometimes happens, however, that a new item receives little or no attention during subsequent weeks, or even months. The textbook goes on to deal with other items. Unless the new item is regularly used and practised, pupils are likely to forget it.

There are some teaching items which are unsuitable for drills. They may, however, be suitable for incidental use. A teacher who has a good command of English, and who sees and uses such opportunities, can do much to help his pupils.

This article suggests ways in which items which have been insufficiently drilled, and items which are unsuitable for drills, may be dealt with incidentally.

The interrogative-negative is an example. The teacher may use it incidentally, whenever opportunities occur. He will be using it as it is normally used, in real situations. He will make it clear that an affirmative answer is expected, even though, in some cases, the answer may be negative. Here are some possibilities.

(1) A pupil appears not to know something which he may reasonably be expected to know. The teacher looks at him and asks, with a rise in pitch on the appropriate word:

Don't you know what lend means?

Don't you know how to spell friend yet?

\footnotetext{
${ }^{1}$ The strong vowel in these unstressed prepositions faintly mirrors the pronunciation of the stressed group: preposition + pronoun, where the full stress falls on the preposition, e.g. Chinking glasses: Here's to you hioz 'tu: ju. When they are with me... 'wen bel o 'wio mi: ...
} 